for example, was vested in three divisions-tenement house inspection, house drainage inspection and nuisance inspection. Laws on the inspection of meat and cattle were enforced by one division, those on milk by another. The disadvantages of such a form of organization are at once apparent. Responsibility is divided, efforts are duplicated, inefficiency results. In order to bring unity and centralization, the departmental organization was studied by the bureau of municipal research. It demonstrated, by means of graphic charts, the illogical sub-division, then existing, and the consolidation necessary for building up a more compact and effective organization. All the changes made by Dr. Neff within the last two years have been in harmony with these suggestions.

Although the above sketch by no means exhausts the list of studies made by the new citizen agency for Dr. Neff's department, it serves to show the range of activities and the nature of this new co-operation of official and citizen. For those of us who believe in the efficiency movement in government Dr. Neff's administration is a most encouraging sign of the ushering in of the new regime. When public officials welcome aid and suggestions and citizens respond to a call so unemotional and disinterested, a real and effective democracy no longer seems a dream.

Neva R. Deardorff, Ph. $D^{1}$.

\title{
CO-OPERATION BETWEEN CITY GOVERNMENTS AND UNIVERSITIES ?
}

$I^{\mathrm{P}}$ THERE is to be proper co-operation between universities and city governments it must be assumed that there is good will on both sides and that the city government wishes to have university co-operation.

Already there has been much done by many universities the country over through scientific investigation of various types made by professors directly for the city government. Civil engineers, architects, bacteriologists, statisticians and others have often worked for city governments to the decided advantage of the city. It is desirable, however, that this co-operation be extended much further.

At the suggestion of the mayor and of the city chamberlain of New York, New York University is now making an inventory of the scientific equipment, both physical and personal, of the city. The purpose is to see whether there may not be worked out some better scientific organization of the city's forces so as to secure some improvement in the service with a reduction of cost. It is hoped that a report will be made in time to be of service to the budget committee.

\footnotetext{
${ }^{1}$ Chief of division of vital statistics, Bureau of Health, Philadelphia.

2 The substance of Prof. Jenks' remarks at the recent conference in New York on the universities and training for public service.-EDrtor.
} 
Beyond, however, the work that may be done by professors and experts, it has been suggested that there may also be helpful co-operation on the part of advanced students. Beyond any question graduate students who are fitting themselves for positions in public administrative work would be greatly benefited if, in addition to their lectures and reading, they could have some actual practice in administration. They would often be glad to secure this practice, either at no expense to the city, or for the payment of merely a minimum living salary while they are getting their training. If two students were to work togethel in this way, dividing the time between them, they could arrange to take the work of one position in the city government, each receiving half-pay for his halftime work. If the positions thus filled were those that would give the students an insight into the principles of government and give them the opportunity for constructive work, it would be of great importance to them. Moreover, the city would doubtless be able to secure in this way a higher grade of work-properly supervised also by the university professor-than they would get from the ordinary employee. It is hoped that some plan like this can be worked out.

Again, in every important city where a civil service commission has the supervision of appointments and promotions, there should be an opportunity for co-operation. In New York many thousands of men each year are promoted from lower to higher positions after passing examinations. The preparation for these examinations is ordinarily a mere cram on the part of the canditates. It would be much better if classes could be held for such men on topics immediately connected with their work, but so taught as to give them a better insight into the principles of government and a broader view of the whole field than they get now. Such classes might well be provided for by universities.

My suggestions would be that as regards classes held for the benefit of city employees, the city itself furnish the room and permit the classes to be held in city time,- say one hour or two hours a week, during a considerable part of the year. The added efficiency of the employees and the certainity of securing a better grade of work would justify this giving of time and rent by the city. The men themselves would profit enough by it, so that they could well afford to pay a reasonable fee for the teacher, properly equipped. The teachers selected by the university should be men entirely competent to handle that work,-in many cases they would have to be members of the faculty. No student should be allowed to practise on the city employees for his own training.

Aside from the city government proper, universities might well co-operate with the citizens in improving conditions. At Government house of New York University, for example, graduate students have organized clubs of young men, frequently voters, sometimes young men who will obtain the vote in two or three years, and in those clubs have taught the 
principles of city administration from as practical a viewpoint as possible. Not only are city institutions visited by these clubs under the leadership of the university men, but young citizens are encouraged to take an active part in their own civic problems. The keeping of the streets clean, the proper inspection of tenement houses, the sanitary care of the markets, even the oversight of dance houses, and similar lines of activity can well be taken up by these clubs very effectively. The leadership of the clubs trains the graduate student as no class-room work alone could do. Whereever a university is preparing men for positions such as secretaries of commercial clubs, or secretaries of social centers,-or for that matter, for any kind of public service,- - the combination of a careful study of the principles with this practical work is of great importance. Wherever it has been tried, under careful supervision with the idea of scientific thoroughness underlying, it seems to have been successful.

In connection with such clubs there has been established at Government house also a municipal information bureau for the use of any citizens who care to get information regarding the city government or their own civic problems. Such work might readily be extended to clubs in churches, in settlements and other places where people are working for the public welfare.

In these ways, and doubtless various others that could be suggested, co-operation between universities and the city government would redound to the benefit of both. ${ }^{3}$

JEREMIAH W. JENKS.

${ }^{3}$ See National Municipal Review, vol. iii, p. 68.

4 Of the New York University. 